\title{
Physicochemical and sensorial characterization of yacon mixed juice with bioactive properties
}

\author{
Daniel Felipe Toro Suárez ${ }^{1}$ Luciana Leite de Andrade Lima ${ }^{(10}$ \\ Thayza Christina Montenegro Stamford ${ }^{1}$ (i) Dayanne Consuelo da Silva $^{2}$ (i) \\ Tiago Gomes Santos ${ }^{2}$ (i) Gerlane Souza de Lima1 ${ }^{1}$ \\ Vivianne Montarroyos Padilha $^{3}$ Tânia Lúcia Montenegro Stamford ${ }^{1 *}$ (1)
}

\footnotetext{
${ }^{1}$ Programa de Pós-graduação em Nutrição, Departamento de Nutrição, Universidade Federal de Pernambuco (UFPE), 50731-250, Recife, PE, Brasil. E-mail: tania.stamford@ufpe.br. "Corresponding author.

${ }^{2}$ Departamento de Tecnologia Rural, Universidade Federal Rural de Pernambuco (UFRPE), Recife, PE, Brasil.

${ }^{3}$ Departamento de Nutrição, Universidade Federal de Pernambuco (UFPE), Recife, PE, Brasil.
}

\begin{abstract}
This study developed a palatable, acceptable, and functional mixed juice of pineapple (Ananas comosus var. Comosus), passion fruit (Passiflora edulis flavicarpa degener), and yacon (Smallanthus sonchifolius), with enhanced bioactive and prebiotic compounds. The ideal proportion of fruit and yacon was derived after planning a mixture with six formulations and by evaluating their bioactive compounds and organic acid profile. The best formulation sensory evaluation was performed by the Just-About-Right test (JAR) and global acceptance. The chosen mixed juice (M6-30\% pineapple, $45 \%$ passion fruit, and 30\% yacon) presented results that showed elevated levels of antioxidant

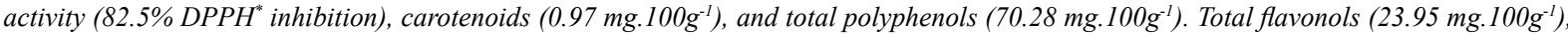
total anthocyanins $\left(1.37 \mathrm{mg} 100 \mathrm{~g}^{-1}\right)$, gallic acid $\left(3.13 \mu \mathrm{g} . \mathrm{mL}^{-1}\right)$, quercetin $\left(2.25 \mu \mathrm{g} . \mathrm{mL}^{-1}\right)$, syringic acid $\left(1.01 \mu \mathrm{g} . \mathrm{mL} \mathrm{L}^{-1}\right)$, citric acid $(949.30$ $\left.\mathrm{mg} 100 \mathrm{~g}^{-1}\right)$, malic acid $\left(140.35 \mathrm{mg} 100 \mathrm{~g}^{-1}\right)$, and $0.58 \%$ of dietary fiber were also reported. Sensorially, consumers perceived high acidity, strong flavor, and a fibrous texture, which might have affected the global acceptance of the juice (6.0). Results indicated the feasibility of obtaining a functional and palatable mixed juice using yacon.
\end{abstract}

Key words: bioactive compounds, dietary fiber, phenolic acids, sensory analysis.

Caracterização físico-química e sensorial de suco misto de yacon com propriedades bioativas

RESUMO: Este estudo objetivou desenvolver suco misto funcional, palatável e aceitável de abacaxi (Ananas comosus var. Comosus), maracujá (Passiflora edulis flavicarpa degenerer) e yacon (Smallanthus sonchifolius), enriquecido com compostos bioativos e prebióticos. A proporção ideal entre as frutas e o yacon foi resultado de planejamento de mistura com seis formulações e avaliação de perfil de compostos bioativos e ácidos orgânicos. A melhor formulação foi avaliada sensorialmente pelo teste Just About Right (JAR) e por aceitação global. O suco misto escolhido (M6 - 30\% de abacaxi, 45\% de maracujá e 30\% de yacon) apresentou altos valores para atividade antioxidante (82,5\% de inibição de DPPH *), carotenoides $(0,97 \mathrm{mg} / 100 \mathrm{~g})$ polifenóis totais (70,28 $\mathrm{mg} / 100 \mathrm{~g})$. Também foram detectados flavonóis totais (23,95 $\mathrm{mg} / 100 \mathrm{~g})$, antocianinas totais $(1,37 \mathrm{mg} / 100 \mathrm{~g})$, ácido gálico $(3,13 \mu \mathrm{g} / \mathrm{mL})$, quercetina $(2,25 \mu \mathrm{g} / \mathrm{mL})$, ácido siríngico (1,01 $\mu \mathrm{g} / \mathrm{mL})$, ácido cítrico $(949,30 \mathrm{mg} / 100 \mathrm{~g})$, ácido málico (140,35 mg/100g) e 0,58\% de fibra alimentar. Sensorialmente, os consumidores perceberam alta acidez, sabor forte e textura fibrosa, o que pode ter afetado a aceitação global $(6,0)$. Os resultados indicam a possibilidade de obtenção de um suco misto funcional e palatável com yacon.

Palavras-chave: compostos bioativos, fibra dietética, ácidos fenólicos, análise sensorial.

\section{INTRODUCTION}

Scientific evidence has shown people's concern about taking better care of their health. Factors such as a sedentary lifestyle, pollution, and bad eating habits lead to the spread of diseases considered silent enemies, such as obesity, diabetes, cancer, hypertension, and atherosclerosis
(ALJAHANI \& CHEIKHOUSMAN, 2017). Functional beverage consumption may reduce the risk for non-communicable diseases (NCDs), due to their benefits for human health (SOUZA et al., 2020). This fact motivates the development of beverages rich in bioactive compounds, with sensorial quality, for example, mixed juices (CARVALHO et al., 2017). 
Mixed juices accomplish this niche in the market, as they have the advantage of nutritional improvement, with complementation of nutrients and development of new flavors (CARVALHO et al., 2017). These juices contain groups of compounds that benefit human health, such as phenolics, carotenoids, terpenes, vitamins, and minerals (ALJAHANI \& CHEIKHOUSMAN, 2017; SOUZA et al., 2020). Bioactive compounds have a protective effect based on antioxidant activity, with free radical sequestration, inhibition of hydrogen peroxide production, and activation of endogenous defense mechanisms (WANG et al., 2018). Moreover, food fibers (fructo-oligosaccharides, polysaccharides, and oligosaccharides) are considered relevant prebiotics. They contributed to gastrointestinal dysfunction and prevention of NCDs, and also increase nutrient uptake and the activity of intestinal beneficial cultures. Food fiber also promotes a sense of fullness and satiety, which is a relevant factor for weight control (MENDES et al., 2019).

Different fruits and vegetables can be used in mixed juices, contributing to their nutritional and sensory characteristics, and tubers, which are rich in food fibers. These functional beverages provide enhanced activity of the bioactive compounds and desirable organoleptic characteristics (PERIN et al., 2015).

Yacon (Smallanthus sonchifolius) is a tuber native to the Andes and cultivated in other regions. This tuber has a sweet taste, firm pulp, and high concentration of prebiotic compounds - fructo-oligosaccharides (FOS) (MARTINS et al., 2011; MENDES et al., 2019). Furthermore, it contains antioxidant compounds - ferulic acid, caffeic acid, esculetin, and esculin (DIONISIO et al., 2017). Yacon can be processed into beverages, obtaining concentrations of $20-30 \%$ FOS in yacon juice (SILVA et al., 2018). Studies have shown that yacon ingestion can be associated with biological effects, such as, immunomodulation (DELGADO et al., 2012), antimicrobial (OJANSIVU et al., 2011), antioxidant (SOUSA et al., 2015), and diabetes risk reduction (DIONISIO et al., 2017).

Pineapple (Ananas comosus L. Merr.) is a tropical fruit with a unique sweet/sour taste, widely consumed and appreciated worldwide (HUANG et al., 2014; TEIXEIRA et al., 2019). Furthermore, this fruit has a significant concentration of proteolytic enzymes, polysaccharides, ascorbic acid, and dietary fiber, which improves human health by contributing to digestion, anti-inflammatory processes, and inhibition of platelet aggregation (HUANG et al., 2014).
Passion fruit (Passiflora edulis flavicarpa Degener) is an exotic fruit with a specific and attractive flavor, cultivated in several countries. This fruit contains significant sugars and organic acids (ascorbic acid), carotenoids, fiber, and phenolic compound concentrations. These compounds are associated with the prevention of human diseases, reducing the risk of cancer and cardiovascular diseases (DEVI RAMAIYA et al., 2013).

These products serve a market focused on natural products that promote health benefits (ANTUNES et al., 2013). Thus, this study elaborated a functional mixed juice with pineapple, passion fruit, and yacon, presenting a high concentration of bioactive and prebiotic substances that is sensorily accepted by consumers.

\section{MATERIALS AND METHODS}

\section{Juice production}

Mature fruits were obtained from local markets, sanitized with sodium hypochlorite $(2.38 \%$ $\mathrm{v} / \mathrm{v})\left(\right.$ Emplura $\left.^{\circledR}\right)$, and de-pulped with a domestic food blender $\left(\mathrm{Oster}^{\mathbb{R}}\right)$, in pulse mode, for 2 minutes. The pulps from pineapple, passion fruit, and yacon were packed separately in high-density polyethylene plastic bags, submitted to pasteurization $\left(75^{\circ} \mathrm{C} / 60\right.$ seconds), and stored at $-20^{\circ} \pm 1{ }^{\circ} \mathrm{C}$, until the moment of use.

\section{Experimental design}

The mixed juice preparation consisted of mixing the pulps without adding water or sweeteners, aiming to produce a whole mixed juice. The composition of the formulation utilized the simplex lattice method, for which each independent variable (pineapple, passion fruit, and yacon) corresponded to three levels of participation percentages in the formulations (PADILHA et al., 2017; TEIXEIRA et al., 2009). The combined variables resulted in six different mixed juices (Table 1).

The selection of the best formulation relied on the Response Surface Method, which related the results of the bioactive compounds and antioxidant activity to the proportions of the ingredients in the formulations. All the fruit pulp, tuber, and the formulation defined by the response surface underwent characterization with regard to their physicochemical aspects.

\section{Physico-chemical analysis Classic parameters}

Soluble solid content quantification applied refractometry; $\mathrm{pH}$, potentiometry; total 
Table 1 - Proportion level of pineapple, passion fruit, and yacon in the mixed juice according to the simplex lattice method.

\begin{tabular}{lccc}
\hline Formulation & & & \\
& & & \\
& Pineapple & Passion fruit & Yacon \\
M1 & 60 & 30 & 10 \\
M2 & 30 & 60 & 10 \\
M3 & 30 & 30 & 40 \\
M4 & 45 & 45 & 10 \\
M5 & 45 & 30 & 25 \\
M6 & 30 & 45 & 25 \\
\hline
\end{tabular}

w/w: weight to weigh.

acidity, the AOAC 942.15 method; reducing and total sugars, titration; ashes, the AOAC 7009 method; total dietary fiber, the AOAC 993.21 method (IAL, 2008). All tests were performed in triplicate.

\section{Spectrophotometric analysis}

The extracts from pulps and mixed juice followed a sequential extraction with $60 \%(\mathrm{v} / \mathrm{v})$ ethanol (Dinâmica ${ }^{\circledR}$ ) aqueous solution, acidified with $2 \%(\mathrm{w} / \mathrm{v})$ citric acid $\left(\operatorname{Merck}^{\circledR}\right)$. The mixture was agitated at $30^{\circ} \pm 2{ }^{\circ} \mathrm{C}$ for 30 minutes. After the extracts' filtration, their final volume was adjusted to $100 \mathrm{~mL}$ with acidified ethanolic solution (ANDRADE et al., 2015). All tests were performed in triplicate.

\section{Total polyphenols}

The concentration of total polyphenols in the extracts was determined by a reaction with a Folin-Ciocalteu reagent (Sigma-Aldrich ${ }^{\circledR}$ ), stabilized with a saturated solution of sodium carbonate (Dinâmica ${ }^{\circledR}$ ). The absorbance was measured at $725 \mathrm{~nm}$ (Spectrophotometer Varian ${ }^{\circledR}$ DAD) with a quartz cuvette (optical path $1 \mathrm{~cm}$ ). The results were expressed in mg. $\mathrm{L}^{-1}$, based on the analytical curve of gallic acid equivalents, $\mathrm{y}=0.09860 \mathrm{x}+0.10755\left(\mathrm{r}^{2}=\right.$ 0.9977) (GIOVANELLI \& BURATTI, 2009).

\section{Antioxidant activity}

Sequestration of 2,2-diphenyl-1picrylhydrazyl $\left(\mathrm{DPPH}^{*}\right) \quad\left(\right.$ Sigma-Aldrich $\left.^{\circledR}\right)$ was evaluated in $100 \mu \mathrm{L}$ of ethanolic extract, diluted to $20 \%$ with methanol $\left(\right.$ Merck $\left.^{\circledR}\right)$. The absorbance was determined at $517 \mathrm{~nm}$ (Spectrophotometer Varian ${ }^{\circledR}$ DAD), after 30 minutes at $25^{\circ} \mathrm{C}$, in the absence of light (NIXDORF \& HERMOSÍN-GUTIÉRREZ,
2010). The percent inhibition was calculated by the following equation:

\%inhibbition $=\frac{\text { aExtract }-(a D P P H-\text { aSolvent })}{a D P P H} \times 100$

Where aDPPH: absorbance of the DPPH ${ }^{*}$ solution and methanol; aSolvent: absorbance of methanol; aExtract: absorbance of extract.

\section{Total carotenoids}

The extraction of total carotenoids was carried out by liquid-liquid extraction with acetone $\left(\right.$ Synth $\left.^{\circledR}\right)$ and petroleum ether (Química Moderna ${ }^{\circledR}$ ). The absorbance reading was performed at $450 \mathrm{~nm}$ in a Spectrophotometer $\operatorname{Varian}^{\circledR}$ DAD. The concentration was calculated according to the following equation, and the results were expressed in $\mu$ geq. of $\beta$-caroten. $\mathrm{g}^{-1}$ (RODRIGEZ-AMAYA, 2001).

$$
\mu \mathrm{g} \text { equivalent of } \beta \text {-caroten. } g-1=\frac{\text { volume } x \text { absorbance } x 10^{6}}{E^{1 \%} \mathrm{~cm} \times \text { sample weight }}
$$

Where, $\mathrm{E}^{1 \%}{ }_{\mathrm{cm}}$ de 2.500 - absorption coefficient.

\section{Total flavonoids and anthocyanins}

Total flavonoids and anthocyanins were extracted with the help of an aqueous and acidified ethanol solution. The samples went through homogenization, refrigeration $\left(5^{\circ} \pm\right.$ $1{ }^{\circ} \mathrm{C}$ ) for 12 hours, protected from light, and filtration. The absorbances at $535 \mathrm{~nm}$ and $374 \mathrm{~nm}$ (Spectrophotometer Varian ${ }^{\circledR}$ DAD) were applied to anthocyanins and flavonoids, respectively. Results of anthocyanins were expressed in $\mathrm{mg} .100 \mathrm{~g}^{-1}$ of cyanidin-3-glucoside equivalent and the results of flavonols were expressed in mg. $100 \mathrm{~g}^{-1}$ of quercetin equivalent (LEES \& FRANCIS, 1972).

Ciência Rural, v.52, n.6, 2022. 
High-performance liquid chromatography analysis Dionex ${ }^{\circledR}$ Ultimate 3000 liquid chromatograph with quaternary pump and molecular absorption detector (UV/Vis) was used. The pulps and mixed juice were analyzed using the Acclaim ${ }^{\circledR} 120$ Dionex C-18 analytical column $(250 \mathrm{~mm} \times 4.6 \mathrm{~mm} \times 5 \mu \mathrm{m})$ for the phenolic (ethanolic extract) and organic acid (direct dilution in ultrapure water) profile determination.

\section{Phenolic profile}

Flavonols $\quad\left(\right.$ Sigma-Aldrich $\left.^{\circledR}\right) \quad$ (rutin, myricetin, quercetin, and kaempferol), phenolic acids (Sigma-Aldrich ${ }^{\circledR}$ ) (gallic, syringic, ellagic, caffeic, vanillic, and p-coumaric), and stilbenes $\left(\right.$ Sigma-Aldrich $\left.^{\circledR}\right) \quad$ (trans-resveratrol) were individually identified and quantified in the samples diluted with the mobile phase. The parameters of the analysis were: Mobile phase flow of $0.6 \mathrm{~mL} . \mathrm{min}^{-1}$, oven temperature of $36{ }^{\circ} \mathrm{C}$, and wavelengths of $220,260,306$, and $368 \mathrm{~nm}$, depending on the absorbance of each compound. The mobile phase consisted of formic acid solutions $(0.5 \% \mathrm{v} / \mathrm{v})$ in MilliQ $^{\circledR}$ water and acetonitrile (Riedel-deHaën ${ }^{\circledR}$ ), in the proportion of 9:1 (solution A) and 1:9 (solution B). The separation of the compounds required a gradient mixture of the solutions $A$ and $\mathrm{B}$ : 0 to 10 minutes, 0 to $10 \% \mathrm{~B} ; 10$ to 30 minutes, 10 to $15 \% \mathrm{~B} ; 30$ to 40 minutes, 15 to $40 \% \mathrm{~B} ; 40$ to 60 minutes, 40 to $60 \% \mathrm{~B}$; and 60 to 70 minutes, 60 to $10 \%$ of B. The quantification was performed by an analytical curve of each standard (0.05 to $\left.4.0 \mu \mathrm{g} . \mathrm{mL}^{-1}, \mathrm{r}^{2}>0.99\right)$ in the mobile phase, with external standardization (LIMA et al., 2011).

\section{Organic acid profile}

Acids were identified and quantified individually at $212 \mathrm{~nm}$ with a mobile phase flow of $0.8 \mathrm{~mL} \cdot \mathrm{min}^{-1}$ and a temperature of $36{ }^{\circ} \mathrm{C}$ in samples diluted with the mobile phase. The mobile phase was prepared with formic acid (Riedel-de-Haën $\left.{ }^{\circledR}\right)(0.12 \%$, v/v) and acetonitrile (Riedel-de-Haën $\left.{ }^{\circledR}\right)(0.1 \%$ v/v). For quantification, the analytical curve solutions $\left(\mathrm{r}^{2}>\right.$ 0.99 ) were used in the mobile phase dilutions, in the following concentration ranges: Oxalic, tartaric, and malic acids, 0.025 to $1.0 \mathrm{mg}$. $\mathrm{mL}^{-1}$, ascorbic acid, 0.1 to $3.0 \mathrm{mg} \cdot \mathrm{mL}^{-1}$, and citric acid 0.01 to $0.2 \mathrm{mg} \cdot \mathrm{mL}^{-1}$. Results were expressed in $\mathrm{mg} .100 \mathrm{~g}^{-1}$ of the product (LIMA et al., 2010).

\section{Sensorial analysis}

This research was approved by the Research Ethics Committee of the Federal University of Pernambuco, according to the standards and guidelines for research involving human subjects (Resolution CNS $\mathrm{n}^{\circ}$ 196/96), CAAE, $\mathrm{n}^{\circ}$ 79471017.5.0000.5208.

The sensorial analysis consisted of a panel of sixty mixed juice consumers (minimum of twice a week) from the Academic Community of the Federal University of Pernambuco.

The Just-About-Right (JAR) test was applied, with five taste attributes (acid taste, sweet taste, taste intensity, fibrous texture, and consistency). The sensorial parameters were presented to the consumers, with a nominal scale of five points 'not perceptible', 'low perceptible', 'ideal', 'highly perceptible', 'extremely perceptible'. Evaluation of the overall quality impression of the mixed juice was also included using nine points in the nominal scale 'really disliked' to 'extremely liked' (DIONISIO et al., 2017; PADILHA et al., 2017). To perform the sensory tests, all consumers received $20 \mathrm{~mL}$ of the mixed juice at $8^{\circ} \pm 2{ }^{\circ} \mathrm{C}$ in disposable glasses, with an evaluation form and a glass of water, for early palate softness.

\section{Statistical analysis}

Results of the physicochemical analysis were obtained in triplicate and presented as means and standard deviations. The total polyphenols, carotenoids, and antioxidant activity results were interpreted by the response surface. Variance analysis (ANOVA) and Duncan's mean test were applied to identify possible differences between the obtained results $(\mathrm{P}<0.05)$. The influence of the Just-AboutRight test results and global acceptance was assessed via a penalty analysis. The statistical procedures were performed using Statistic 7.0 software $^{\circledR}$ and Software XLStat $2017^{\circledR}$ (Addinsoft, Paris, France).

\section{RESULTS AND DISCUSSION}

Table 2 shows the results of bioactive compounds and the antioxidant activity of the components in the functional mixed juice. Passion fruit showed the best bioactive composition. Previous studies reported a lower (0.761-5.442 mg gallic acid equivalent $\mathrm{g}^{-1}$ ) (CARVALHO et al., 2018) or higher (342.80-382.00 mg gallic acid equivalent $\mathrm{L}^{-1}$ ) (DEVI RAMAIYA et al., 2013) total polyphenol concentration than in the present research.

\section{Identification of the best formulation}

Concentrations of the main bioactive compounds and the antioxidant activity were considered to select the best formulation of the mixed juice. According to the response surface, 
Table 2 - Bioactive compounds and antioxidant activity of the pulps used to prepare the mixed juice.

\begin{tabular}{|c|c|c|c|c|c|}
\hline Pulps & $\begin{array}{l}\text { Carotenoids } \\
\left(\mathrm{mg} .100 \mathrm{~g}^{-1}\right)\end{array}$ & $\begin{array}{l}\text { Total Polyphenols } \\
\left(\mathrm{mg} \mathrm{GAE} .100 \mathrm{~g}^{-1}\right)\end{array}$ & $\begin{array}{l}\text { Antioxidant activity } \\
\text { (\% DPPH* inhibition) }\end{array}$ & $\begin{array}{c}\text { Total } \\
\text { anthocyanins }\end{array}$ & $\begin{array}{c}\text { Total } \\
\text { flavonoids }\end{array}$ \\
\hline Pineapple & $0.056^{\mathrm{c}} \pm 0.100$ & $63.46^{\mathrm{a}} \pm 0.07$ & $72.65^{\mathrm{a}} \pm 2.22$ & $1.48 \mathrm{~b} \pm 0.011$ & $10.12 \mathrm{c} \pm 0.060$ \\
\hline Passion fruit & $1.898^{\mathrm{a}} \pm 0.080$ & $53.50^{b} \pm 0.63$ & $62.26^{\mathrm{b}} \pm 1.72$ & $1.63 \mathrm{a} \pm 0.012$ & $37.18 \mathrm{a} \pm 0.217$ \\
\hline Yacon & $0.223^{\mathrm{b}} \pm 0.020$ & $41.98^{c} \pm 0.00$ & $65.36^{\mathrm{b}} \pm 1.53$ & $1.45 b \pm 0.010$ & $38.87 \mathrm{a} \pm 0.216$ \\
\hline
\end{tabular}

${ }^{*}$ Different letters in the same column indicate significant difference by the Duncan's test $(\mathrm{P}<0.05)$.

the formulation with the most relevant functional potential was M6 (30\% pineapple, $45 \%$ passion fruit, and $25 \%$ yacon), indicated by table 3 and figure 1 . Furthermore, figure 1a shows the influence of pineapple and yacon on the increased antioxidant activity. Figures $1 \mathrm{~b}$ and $1 \mathrm{c}$ show that the ideal range of the passion fruit is between $30 \%$ and $60 \%$ in the mix composition, similar to the statistical projection observed in table 1.

All response surfaces (Figure 1) showed that mixed juice M6 presents higher carotenoid and total polyphenol contents, as well as a significant percentage of antioxidant activity. This mixed juice registered a higher total polyphenol concentration (70.28 mg GAE. $100 \mathrm{~g}^{-1}$ ) than the data reported in other mixed drinks with yacon $\left(66.52 \mathrm{mg} .100 \mathrm{~g}^{-1}\right)$ (DIONISIO et al., 2017). However, the recommended daily intake is $2,500-3,000 \mathrm{mg}$ (ROLDÁN \& AZCONA, 2009).

With regard to carotenoids, the selected mixed juice may correspond to a good source of this group of compounds $\left(0.97 \mathrm{mg} .100 \mathrm{~g}^{-1}\right)$, as the consumption of $400 \mathrm{~g}$ of the drink per day satisfies their daily recommendation (3-4.3 mg.day $\left.{ }^{-1}\right)$ (ROLDÁN \& AZCONA, 2009). The high content of carotenoids characterizes the juice as a source of vitamin A precursors, crucial for ocular and dermal health (PETTIFOR et al., 2018).

The blend M6 presents itself as an antioxidant juice $(82.50 \%)$, probably because of its relevant content of polyphenols and carotenoids, which indicated this sample's functional potential. Therefore, M6 underwent further physicochemical and sensory characterizations.

\section{Physicochemical characterization of mixed juice}

Pineapple and passion fruit showed a $\mathrm{pH}$ and total acidity (Table 4) similar to other studies (CARVALHO et al., 2018; GERMER et al., 2017). The physicochemical characterization of yacon showed a higher $\mathrm{pH}$, but a low soluble solid content. Variations in the compositions could be due

Table 3 - Bioactive compounds and antioxidant activity of the mixed juice, according to the experimental design (simplex lattice method).

\begin{tabular}{lccc}
\hline Formulation & Carotenoids $\left(\mathrm{mg} .100 \mathrm{~g}^{-1}\right)$ & Total Polyphenols $\left(\mathrm{mg} \mathrm{GAE} .100 \mathrm{~g}^{-1}\right)$ & Antioxidant activity $(\%$ DPPH inhibition) \\
\hline M1 & $0.539^{\mathrm{d}} \pm 0.520$ & $56.61^{\mathrm{c}} \pm 0.50$ & $81.57^{\mathrm{c}} \pm 0.62$ \\
M2 & $0.934^{\mathrm{a}} \pm 0.070$ & $70.01^{\mathrm{b}} \pm 0.47$ & $78.91^{\mathrm{d}} \pm 1.91$ \\
M3 & $0.641^{\mathrm{c}} \pm 0.410$ & $52.19^{\mathrm{d}} \pm 0.58$ & $86.04^{\mathrm{a}} \pm 1.17$ \\
M4 & $0.817^{\mathrm{b}} \pm 0.050$ & $72.04^{\mathrm{a}} \pm 1.62$ & $76.36^{\mathrm{d}} \pm 0.42$ \\
M5 & $0.862^{\mathrm{b}} \pm 0.240$ & $48.08^{\mathrm{e}} \pm 0.07$ & $84.56^{\mathrm{a}, \mathrm{b}} \pm 1.32$ \\
M6 & $0.970^{\mathrm{a}} \pm 0.590$ & $70.28^{\mathrm{b}} \pm 1.50$ & $82.50^{\mathrm{b}, \mathrm{c}} \pm 1.19$ \\
\hline
\end{tabular}

Different letters in the same column indicate significant difference by the Duncan's test $(\mathrm{P}<0.05)$. 


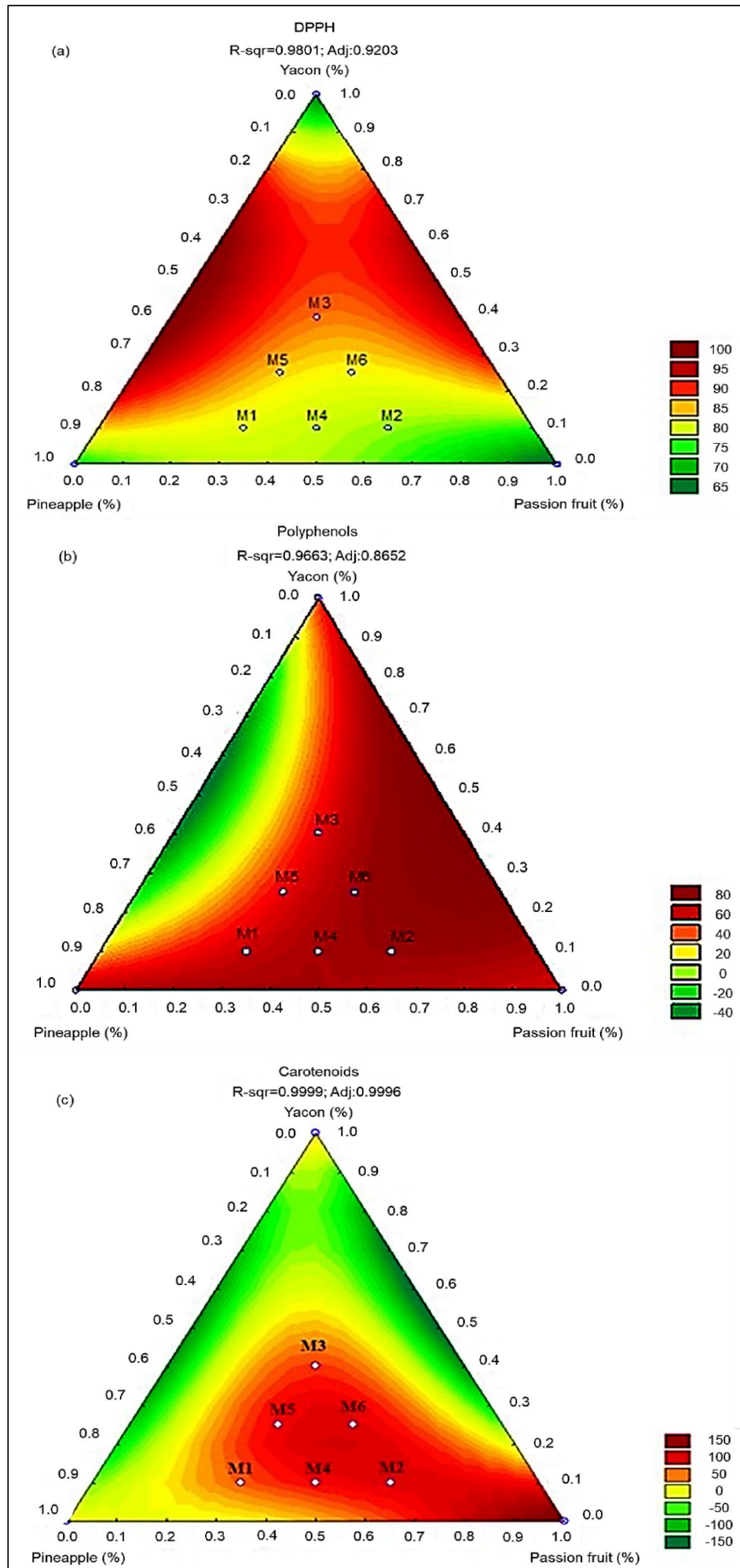

Figure 1 - Relationship between bioactive compounds, biological activity, and sample composition, being: (a) percent inhibition of $\mathrm{DPPH}^{*} \mathrm{x}$ mixed juice composition, (b) total polyphenols $\mathrm{x}$ mixed juice composition, (c) carotenoids $\mathrm{x}$ mixed juice composition. 
Table 4 - Physicochemical classic parameter characterizations of pulps and mixed juice of pineapple, passion fruit, and yacon.

\begin{tabular}{|c|c|c|c|c|}
\hline \multirow[t]{2}{*}{ Physico-chemical parameters } & \multicolumn{3}{|c|}{ 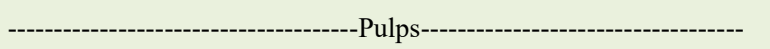 } & \multirow[t]{2}{*}{-------Mixed juice ${ }^{*}-------$} \\
\hline & Pineapple & Passion fruit & Yacon & \\
\hline $\mathrm{pH}$ & $4.00^{\mathrm{b}} \pm 0.05$ & $3.50^{\mathrm{d}} \pm 0.04$ & $7.50^{\mathrm{a}} \pm 0.01$ & $3.70^{\mathrm{c}} \pm 0.05$ \\
\hline Total solids $\left({ }^{\circ}\right.$ Brix $)$ & $14.00^{\mathrm{a}} \pm 0.15$ & $10.50^{\mathrm{c}} \pm 0.25$ & $4.50^{\mathrm{d}} \pm 0.10$ & $12.00^{\mathrm{b}} \pm 0.10$ \\
\hline Total acidity $(\% \mathrm{w} / \mathrm{w})$ & $0.72^{c} \pm 0.04$ & $3.22^{\mathrm{a}} \pm 0.18$ & $0.07^{\mathrm{d}} \pm 0.01$ & $1.68^{\mathrm{b}} \pm 0.01$ \\
\hline Total sugar $(\% \mathrm{w} / \mathrm{w})$ & $8.31^{\mathrm{a}} \pm 0.18$ & $4.44^{\mathrm{d}} \pm 0.08$ & $4.83^{c} \pm 0.04$ & $7.47^{b} \pm 0.05$ \\
\hline Reducing sugar $(\% \mathrm{w} / \mathrm{w})$ & $2.62^{\mathrm{a}} \pm 0.08$ & $2.33^{\mathrm{b}} \pm 0.04$ & $2.40^{\mathrm{b}} \pm 0.02$ & $2.71^{\mathrm{a}} \pm 0.08$ \\
\hline Ash content $(\% \mathrm{w} / \mathrm{w})$ & $0.38^{\mathrm{c}} \pm 0.00$ & $0.85^{\mathrm{a}} \pm 0.02$ & $0.26^{\mathrm{d}} \pm 0.00$ & $0.50^{\mathrm{b}} \pm 0.01$ \\
\hline Dietary fiber $(\% \mathrm{w} / \mathrm{w})$ & $0.27^{\mathrm{d}} \pm 0.00$ & $0.49^{\mathrm{c}} \pm 0.00$ & $1.54^{\mathrm{a}} \pm 0.01$ & $0.58^{\mathrm{b}} \pm 0.00$ \\
\hline
\end{tabular}

${ }^{*}$ Mixed juice (M6) contains $0.30,0.45$ and 0.25 of pineapple, passion fruit and yacon, respectively.

Different letters in the same line indicate significant difference by the Duncan's test $(\mathrm{P}<0.05)$.

to the seasons of the year and planting conditions (OLIVEIRA et al., 2018). The mixed juice selected in this research presented the acidity of the passion fruit, the sweetness of pineapple, and the fiber of yacon.

The mixed juice can be considered a good source of this prebiotic, as it is composed of fiber content that is more superior than that of functional pumpkin juice $(0.16 \%)$ and there are similar results for carrot juice $(0.65 \%)$ (ALJAHANI \& CHEIKHOUSMAN, 2017). Higher fiber intake helps reduce blood pressure levels and prevents diseases such as obesity, diabetes, and cardiovascular disease (MENDES et al., 2019). Furthermore, the mixed juice presented a whole composition without adding ingredients such as water or sweetener.

\section{Bioactive compounds and antioxidant activity}

Tables 2 and 3 show results of total polyphenols, carotenoids, and antioxidant activity in pulps (pineapple, passion fruit, and yacon) and the chosen mixed juice formulation (M6). This formulation showed higher values than the pulps and was also significantly different $(\mathrm{P}<0.05)$ regarding the concentration of total polyphenols $(70.28 \mathrm{mg}$ GAE. $\left.100 \mathrm{~g}^{-1}\right)$ and carotenoids $\left(0.97 \mathrm{mg} .100 \mathrm{~g}^{-1}\right)$, which reflected on its high percentage of antioxidant activity (82.50\% $\mathrm{DPPH}^{*}$ inhibition). Total polyphenols and antioxidant activity values were higher than the mixed beverage with apple juice and cardamom tea (SOUZA et al., 2020). However, these values were lower than those reported in the drink composed of tropical fruits and yacon (DIONISIO et al., 2020). The high total polyphenol and carotenoid concentrations in the mixed juice contributed to the antioxidant activity.
These substances capture reactive oxygen species, induce the cellular antioxidant system, and prevent diseases (DUARTE \& PÉREZ-VIZCAÍNO, 2015).

The pulps presented low total anthocyanins concentration (Table 2), and mixed juice showed 1.37 $\mathrm{mg} .100 \mathrm{~g}^{-1}$. Moreover, passion fruit and yacon showed higher amounts of total flavonols (Table 2). However, pineapple (Table 2) and mixed juice - M6 (23.95 mg. $\left.100 \mathrm{~g}^{-1}\right)$ showed lower concentrations of this class and differed significantly $(\mathrm{P}<0.05)$. The concentration of total flavonols in the mixed juice showed that 100 $\mathrm{g}$ is sufficient to supply the daily requirement (20-26 mg.day ${ }^{-1}$ ) (BRESCIANI et al., 2017). The reduction of total flavonols in the mixed juice can be associated with processing, pasteurization, and storage of the product, causing enzymatic and chemical degradation (SILVA et al., 2011).

Table 5 shows the phenolic profile of pulps and mixed juice. Regardless of the pulps' concentrations, the mixed juice presented the highest diversity and phenolic concentration of the compounds. Flavanols (quercetin, kaempferol, and myricetin) have antitumor, antioxidant, and antiinflammatory activities. Quercetin (2.251 $\left.\mu \mathrm{g} \cdot \mathrm{mL}^{-1}\right)$, a relevant flavonol in mixed juice, can help prevent eye and cardiovascular disease, treat asthma and allergies (WANG et al., 2018). With regard to phenolic acids (Table 5), the most abundant amount has been found in gallic acid, which is seen in passion fruit (6.109 $\left.\mu \mathrm{g} \cdot \mathrm{mL}^{-1}\right)$, yacon (3.065 $\left.\mu \mathrm{g} \cdot \mathrm{mL}^{-1}\right)$, and mixed juice $\left(3.133 \mu \mathrm{g} \cdot \mathrm{mL}^{-1}\right)$. Gallic acid is described as an antioxidant and antitumor/anticarcinogenic, antibiotic, anti-inflammatory (KAHKESHANI et al., 2019; SANTHOSHA et al., 2013). 
Table 5 - Phenolic profile of pulps and mixed juice in the mixed juice of pineapple, passion fruit, and yacon.

\begin{tabular}{|c|c|c|c|c|}
\hline \multirow[t]{2}{*}{ Phenolic compound $\left(\mu \mathrm{g} \cdot \mathrm{mL}^{-1}\right)$} & \multicolumn{3}{|c|}{ 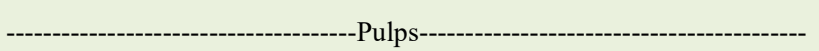 } & \multirow[t]{2}{*}{-------Mixed juice*----- } \\
\hline & Pineapple & Passion fruit & Yacon & \\
\hline Quercetin & NQ & NQ & NQ & $2.251 \pm 0.001$ \\
\hline Kaempferol & NQ & NQ & NQ & $0.193 \pm 0.000$ \\
\hline Myricetin & NQ & NQ & NQ & $0.819 \pm 0.000$ \\
\hline Vanillic Acid & NQ & NQ & NQ & $0.654 \pm 0.000$ \\
\hline Siringic Acid & NQ & NQ & NQ & $1.011 \pm 0.000$ \\
\hline Gallic acid & $0.801^{\mathrm{d}} \pm 0.000$ & $6.109^{\mathrm{a}} \pm 0.000$ & $3.065^{\mathrm{c}} \pm 0.000$ & $3.133^{\mathrm{b}} \pm 0.000$ \\
\hline Ferulic acid & NQ & NQ & NQ & $0.796 \pm 0.000$ \\
\hline p-coumaric acid & $0.438^{\mathrm{c}} \pm 0.000$ & $0.529^{\mathrm{b}} \pm 0.000$ & $0.096^{\mathrm{d}} \pm 0.000$ & $0.907^{\mathrm{a}} \pm 0.000$ \\
\hline Total phenolics & 1.239 & 6.638 & 3.161 & 9.764 \\
\hline
\end{tabular}

*Mixed juice (M6) contains $0.30,0.45$ and 0.25 of pineapple, passion fruit and yacon, respectively. Limit of Quantification (LOQ) for each substance equals $0.05 \mu \mathrm{g} \cdot \mathrm{mL}^{-1}$. NQ: Not quantifiable. Different letters in the same line indicate significant difference by the Duncan's test $(\mathrm{P}<0.05)$.

\section{Organic acid profile}

The profiles of the organic acids in the pulp and mixed juice are shown in table 6 . The predominant acid in the mixed juice was citric acid (949.30 mg.L $\mathrm{L}^{-1}$ ), followed by malic acid (140.35 mg.L $\mathrm{L}^{-1}$ ), both having passion fruit as their most significant source (Table 6). According to the chromatographic readings, oxalic acid, among those evaluated, was the only acid in yacon.

The high content of organic acids was probably responsible for the high titratable acidity of the mixed juice, as every acid contributes to hydrogen dissociation and the grade of combination of their salts (RIBÉREAU-GAYON et al., 2006). The high citric acid content and malic acid concentration in the juice conferred the fruit's characteristic flavors and increased food conservation (BRESCIANI et al., 2017).

Citric acid showed the highest reduction in its concentration $(42.08 \%)$ following the mixed juice preparation (Table 6). The pasteurization process degraded organic acids, especially citric acid (ORJUELA \& VANEGAS, 2012), as observed in this study.

The mixed juice presented moderate oxalic acid concentration (48.40 mg.L $\mathrm{L}^{-1}$ ) (Table 6). However, oxalic acid in elevated concentrations could hinder the assimilation of some minerals (iron, calcium,

Table 6 - Profile of organic acids in the pulps and mixed juice of pineapple, passion fruit, and yacon.

\begin{tabular}{|c|c|c|c|c|}
\hline Organic acids $\left(\mathrm{mg} \cdot 100 \mathrm{~mL}^{-1}\right)$ & 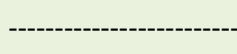 & --Pulps------------ & ----------------- & -----Mixed juice*---- \\
\hline & Pineapple & Passion fruit & Yacon & \\
\hline Oxalic & $31.60^{\mathrm{c}} \pm 0.20$ & $45.70^{\mathrm{b}} \pm 0.10$ & $28.70^{\mathrm{d}} \pm 0.50$ & $48.40^{\mathrm{a}} \pm 0.20$ \\
\hline Tartaric & NQ & $3.70 \pm 0.37$ & NQ & NQ \\
\hline Malic & $159.50^{\mathrm{b}} \pm 0.10$ & $236.75^{\mathrm{a}} \pm 9.05$ & NQ & $140.35^{\mathrm{c}} \pm 0.35$ \\
\hline L-ascorbic & NQ & $6.65 \pm 0.55$ & NQ & NQ \\
\hline Citric & $648.00^{c} \pm 0.30$ & $3,208.60^{\mathrm{a}} \pm 7.40$ & NQ & $949.30^{b} \pm 5.00$ \\
\hline
\end{tabular}

"Mixed juice (M6) contains $0.30,0.45$ and 0.25 of pineapple, passion fruit and yacon, respectively. Limit of Quantification (LOQ) for each substance equals $0.025 \mathrm{mg} \cdot \mathrm{mL}^{-1}$ (oxalic, tartaric, and malic acids), $0.1 \mathrm{mg} \cdot \mathrm{mL}^{-1}$ (ascorbic acid), and $0.01 \mu \mathrm{g} \cdot \mathrm{mL}^{-1}$ (citric acid). NQ: Not quantifiable. Different letters in the same line indicate significant difference by the Duncan's test $(\mathrm{P}<0.05)$. 
and magnesium) by reacting with them and forming oxalate salts (WOBETO et al., 2007).

\section{Sensory analysis}

The sensorial results of the consumers measured the intensity of specific sensory attributes by the Just-About-Right test (JAR) and global acceptance (Table 7). Through this test, the characteristics of the ideal standard (2.5) considered by the consumers were verified, such as acidity, consistence, fibrous texture, and intensity of taste (Table 7).

The acid taste is slightly above (3.3) the ideal point, indicating that the product is more acidic than the panelists appreciated. Furthermore, the sweetness level is insufficient for the consumers (Table 7). The high values of total acidity (Table 4), citric and malic acid concentrations (Table 6), and low soluble solid content $\left(12^{\circ} \mathrm{Brix}\right)$ may be responsible this result. The high content of organic acids may hinder the acid-sweet balance perception in the product. Furthermore, it is fundamental to consider the sweet taste in fruit juices with high levels of acid (FREITAS \& MATTIETTO, 2013), and the preference for these basic tastes varies according to the product and also according to the population (FREITAS et al., 2014; ROCHA \& BOLINI, 2015). Adding sugar is a common practice to make the product more palatable. As the objective of this research was to produce a whole mixed juice, adding water and sugar to the formulations was not reasonable.

The intensity taste (3.7) and the consistency (3.5) were above the ideal point, indicating a surplus of these characteristics. As the juice consisted only of fruit pulp, the lack of dilution could be responsible for this perception. The perception of the fibrous texture
(Table 7) indicated that the product had a far superior fiber concentration than expected by the consumers, corroborating a sensory study of yogurts with yacon (MENDES et al., 2019).

Figure 2 shows the graphic penalty results on global acceptance, corroborated by applying JAR tests to connect consumer acceptance tests with the intensity of specific attributes (NARAYANAN et al., 2014). However, parameter levels evaluated by less than $20 \%$ of the panelists were not significant once they showed very selective preferences, and values below the mean drop limit (1) did not influence global acceptance (FERNÁNDEZ SEGOVIA et al., 2018). Therefore, the product's overall acceptance could be made superior by decreasing flavor intensity, acid taste, and fibrous texture, and increasing sweetness.

\section{CONCLUSION}

The different formulations prepared in this study contributed to identifying an ideal combination of pineapple, passion fruit, and yacon, to produce a functional mixed juice, based on the response surface analysis of bioactive compound concentrations versus fruit proportion. The best formulation showed high antioxidant activity and content of carotenoids and total polyphenols. Sensorially, consumers perceived high acidity, intense flavor, and fibrous texture. Results indicated the possibility of obtaining a functional and palatable mixed juice using yacon. A satisfactory acceptance of functional beverages, such as the one elaborated herein, reinforces the development of food products that can fulfill this niche in the market, add value to different fruits and vegetables, and collaborate to improve eating habits and health benefits.

Table 7 - Evaluation of sensory analysis - Just-About-Right (JAR) and global acceptance, for the mixed juice ${ }^{*}$ of pineapple, passion fruit, and yacon.

\begin{tabular}{lcc}
\hline Test & Sensory Attribute & Result \\
& Acid taste & $3.3 \pm 0.9$ \\
& Sweet taste & $2.1 \pm 0.8$ \\
Just-About-Right (JAR) & Intensity of taste & $3.7 \pm 0.7$ \\
& Fibrous texture & $3.5 \pm 0.8$ \\
& Consistency & $3.5 \pm 0.6$ \\
Global acceptance & & $6.0 \pm 1.8$ \\
\hline
\end{tabular}

*Mixed juice (M6) contains $0.30,0.45$ and 0.25 of pineapple, passion fruit and yacon, respectively. 


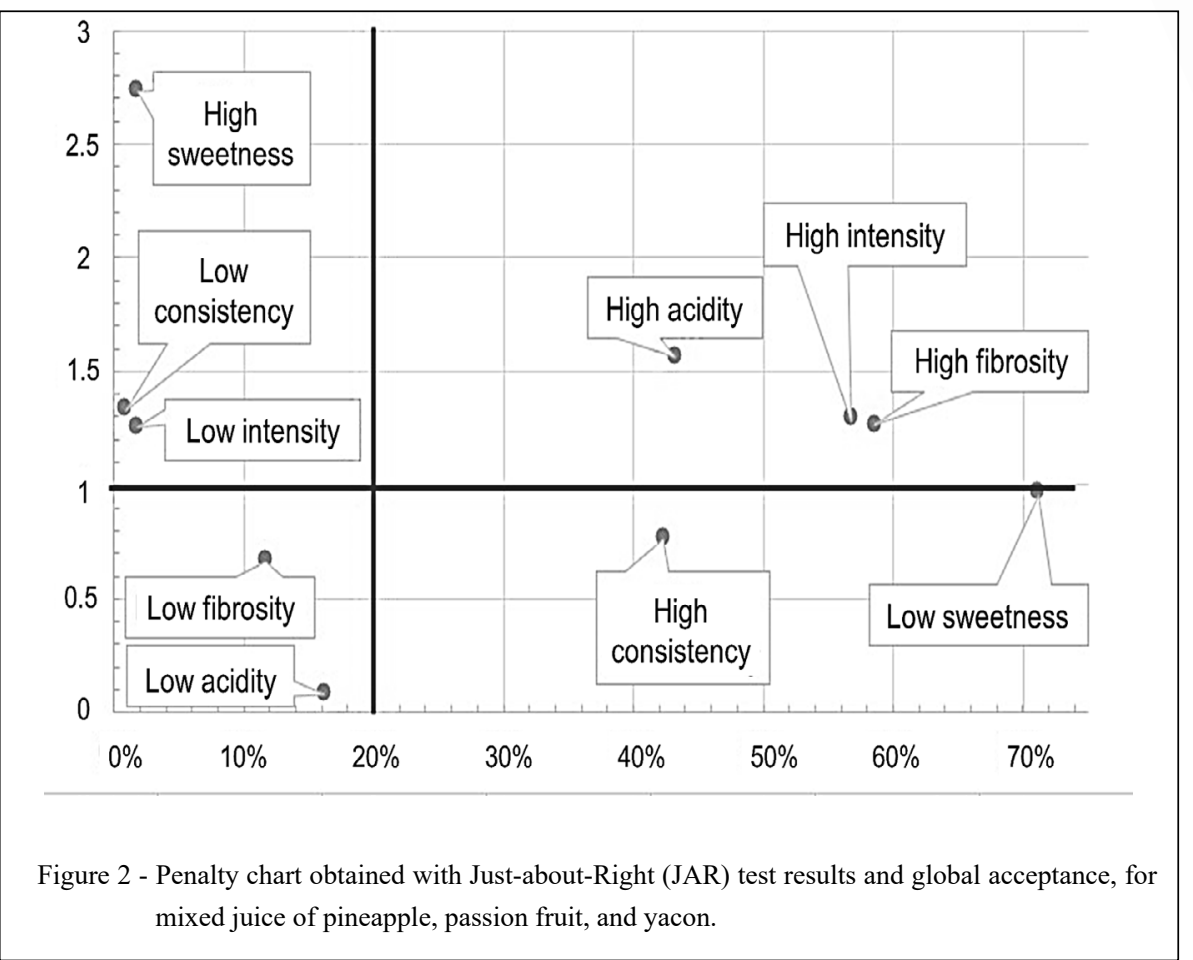

\section{ACKNOWLEDGMENTS}

The authors thank the Coordenação de Aperfeiçoamento de Pessoal de Nível Superior (process $n^{\circ}$ CAPES/ PROEX 1734/2015), the Conselho Nacional de Desenvolvimento Científico e Tecnológico - CNPq (process $n^{\circ} 436172 / 2018-6$ ), and the Pró-reitoria de Pesquisa e Pós-graduação da Universidade Federal de Pernambuco - PROPESQ/UFPE (process $\mathrm{n}^{\circ}$ 23076.049914/2017-47) for their financial support.

\section{DECLARATION OF CONFLICT OF INTEREST}

We have no conflict of interest to declare

\section{AUTHORS' CONTRIBUTIONS}

All authors contributed equally to the conception and writing of the manuscript. All authors critically revised the manuscript and approved of the final version.

\section{REFERENCES}

ALJAHANI, A.; CHEIKHOUSMAN, R. Nutritional and sensory evaluation of pumpkin-based (Cucurbita maxima) functional juice. Nutrition \& Food Science, v. 47, n. 3, p. 346-356, 8 maio 2017. Available from: <https:/www.emerald.com/insight/ content/doi/10.1108/NFS-07-2016-0109/full/pdf?title=nutritional- and-sensory-evaluation-of-pumpkin-based-italiccucurbitamaximaitalic-functional-juice>. Accessed: Sep. 20, 2019. doi: 10.1108/NFS-07-2016-0109.

ANDRADE, R. A. M. de S. et al. Optimization of the extraction process of polyphenols from cashew apple agro-industrial residues. Food Science and Technology (Campinas), v. 35, n. 2, p. 354-360, jun. 2015. Available from: <https://www.scielo.br/j/ cta/a/mmmYS9YVqywVfPj7s5CnkwR/?lang=en\&format=pdf $>$. Accessed: Sep. 20, 2019. doi: 10.1590/1678-457X.6585.

ANTUNES, A. E. C. et al. Acerola nectar with added microencapsulated probiotic. LWT - Food Science and Technology, v. 54, n. 1, p. 125-131, nov. 2013. Available from: $\quad<$ https://www.sciencedirect.com/science/article/pii/ S0023643813001473? casa token=NnOFRacaNd8AAAAA:Onvp 07DfAF9CxgxI5UakimVY9JyrEDYRd-er3wH_Ph6-g_dk7fInaXzIjgXS9J1Og6mOCkvBoI>. Accessed: Jul. 15, 2019. doi: 10.1016/j.lwt.2013.04.018.

BRESCIANI, L. et al. Absorption Profile of (Poly)Phenolic Compounds after Consumption of Three Food Supplements Containing 36 Different Fruits, Vegetables, and Berries. Nutrients, v. 9 , n. 3, p. 194, 26 fev. 2017. Available from: $<$ https://www.mdpi. com/2072-6643/9/3/194>. Accessed: Jul. 15, 2019. doi: 10.3390/ nu9030194.

CARVALHO, A. V. et al. Estudo da estabilidade de polpas de frutas tropicais mistas congeladas utilizadas na formulação de bebidas. Brazilian Journal of Food Technology, v. 20, 2017. Available from: $<$ https://www.scielo.br/j/bjft/a/w5QgYLb5RsrvXmz7hHNr6Tt/ 
abstract/?lang=pt $>$. Accessed: Jul. 15, 2019. doi: 10.1590/19816723.2316 .

CARVALHO, M. V. O. et al. Pre-harvest factors related to sensory profile of Passiflora setacea nectars, a wild passion fruit from Brazilian savannah. Journal of the Science of Food and Agriculture, v. 98, n. 15, p. 5711-5722, dez. 2018. Available from: $<$ https://onlinelibrary.wiley.com/doi/full/10.1002/jsfa.9118?casa EPyqBbhuF1812ghDH6uky4HlHE3gM0rNzSz5sg4bxu5c9Ct $>$. Accessed: Jul. 15, 2019. doi: 10.1002/jsfa.9118.

DELGADO, G. T. C. et al. Yacon (Smallanthus sonchifolius)derived fructooligosaccharides improves the immune parameters in the mouse. Nutrition Research, v. 32, n. 11, p. 884-892, nov 2012. Available from: <https://www.sciencedirect.com/science/ article/pii/S0271531712001947>. Accessed: Jul. 15, 2019. doi: 10.1016/j.nutres.2012.09.012.

DEVI RAMAIYA, S. et al. Sugars, ascorbic acid, total phenolic content and total antioxidant activity in passion fruit (Passiflora) cultivars. Journal of the Science of Food and Agriculture, v. 93, n. 5, p. 1198-1205, 30 mar. 2013. Available from: <https:// onlinelibrary.wiley.com/doi/full/10.1002/jsfa.5876? casa token=T5aKwxFxWE8AAAAA\%3AbbJELr9qfHLI Mw2v1 _ 4TOLIKlaGY6odQLWeF2LVwowl3NXw1ugKtO2icASWqJz DSAskILlIaOs7XOt $>$. Accessed: Jul. 15, 2019. doi: 10.1002/ jsfa.5876.

DIONISIO, A. P. et al. Processamento e estabilidade de uma bebida de caju e yacon durante o armazenamento sob refrigeração. Brazilian Journal of Food Technology, v. 21, 21 set. 2017. Available from: <https://www.scielo.br/j/bjft/ a/87bc3TvFZvnwcdMxcZPvSBD/abstract/?lang=pt>. Accessed: Jul. 15, 2019. doi: 10.1590/1981-6723.18916.

Antioxidant and prebiotic effects of a beverage composed by tropical fruits and yacon in alloxan-induced diabetic rats. Food Science and Technology, v. 40, n. 1, p. 202-208, mar. 2020. Available from: <https://www.scielo.br/j/cta/a/ MRqndF $573 \mathrm{cmW} 7 \mathrm{YZrdP} 5 \mathrm{PrXf} /$ ? format $=\mathrm{html} \&$ lang $=\mathrm{en}>$. Accessed: Jun. 22, 2020. doi: 10.1590/fst.34518.

DUARTE, J.; PÉREZ-VIZCAÍNO, F. Protección cardiovascular con flavonoides: enigma farmacocinético. Ars Pharmaceutica (Internet), v. 56, n. 4, p. 193-200, dez. 2015. Available from: <https://scielo.isciii.es/pdf/ars/v56n4/revision2.pdf $>$. Accessed: Jul. 15, 2019. doi: 10.4321/S2340-98942015000400002.

FERNÁNDEZ SEGOVIA, I. et al. Aplicación de las escalas de punto ideal o Just-About-Right (JAR) en análisis sensorial de alimentos. 2018. Available from: <https://riunet.upv.es/ handle/10251/104054>. Accessed: Jul. 15, 2019. doi: hdl.handle. net/10251/104054

FREITAS, D. D. G. C.; MATTIETTO, R. DE A. Ideal sweetness of mixed juices from Amazon fruits. Ciência e Tecnologia de Alimentos, v. 33, p. 148-154, fev. 2013. Available from: $<$ https://www.scielo.br/j/cta/a/xTnCgt7jSR7wPtCbV7y8WRN/ abstract/?lang=en $>$. Accessed: Jul. 15, 2019. doi: 10.1590/S010120612013000500022.

FREITAS, M. L. F. et al. Development of pitanga nectar with different sweeteners by sensory analysis: ideal pulp dilution, ideal sweetness, and sweetness equivalence. Food Science and Technology, v. 34, n. 1, p. 174-180, 11 mar. 2014 Available from: <https://www.scielo.br/scielo.php?script=sci
arttext\&pid=S0101-20612014000100025>. Accessed: Jul. 15, 2019. doi: 10.1590/S0101-20612014005000008.

GERMER, S. P. M. et al. Fruit dragée formulated with reused solution from pineapple osmotic dehydration. Pesquisa agropecuária brasileira, v. 52, n. 9, p. 806-813, 2017. Available from: $\quad<$ https://www.scielo.br/j/pab/a/9JmVZLj9DTvdc3HCg5 $\mathrm{VCXcP} /$ ?lang $=$ en\& format $=\mathrm{html}>$. Accessed: Jul. 15, 2019. doi: 10.1590/S0100-204X2017000900013.

GIOVANELLI, G.; BURATTI, S. Comparison of polyphenolic composition and antioxidant activity of wild Italian blueberries and some cultivated varieties. Food Chemistry, v. 112, n. 4, p. $903-$ 908, 15 fev. 2009. Available from: <https://www.sciencedirect. com/science/article/abs/pii/S0308814608007760>. Accessed: Jul. 15, 2019. doi: 10.1016/j.foodchem.2008.06.066.

HUANG, Y.-L. et al. Water-insoluble fiber-rich fraction from pineapple peel improves intestinal function in hamsters: evidence from cecal and fecal indicators. Nutrition Research, v. 34, n. 4, p. 346-354, abr. 2014. Available from: <https://www.sciencedirect. com/science/article/abs/pii/S0271531714000396>. Accessed: Jul. 15, 2019. doi: 10.1016/j.nutres.2014.03.001

IAL. INSITITUTO ADOLFO LUTZ. Métodos físicos-químicos para análise de alimentos. 4. ed. São Paulo, 2008.

KAHKESHANI, N. et al. Pharmacological effects of gallic acid in health and diseases: A mechanistic review. Iranian journal of basic medical sciences, v. 22, n. 3, p. 225, 2019. Available from: <https://www.ncbi.nlm.nih.gov/pmc/articles/PMC6528712/>. Accessed: Jul. 15, 2019. doi: 10.22038/ijbms.2019.32806.7897.

LEES, D. H.; FRANCIS, F. J. Standardization of pigment analyses in cranberries. HortScience, 1972. Available from: $<$ https://agris. fao.org/agris-search/search.do?recordID=US201302263142>. Accessed: Jul. 15, 2019

LIMA, L. L. A. et al. Physicochemical characterization of tropical wines produced in the Northeast of Brazil. Acta Horticulturae, n. 910, p. 131-134, out. 2011. Available from: <https://www.actahort. org/members/showpdf?booknrarnr $=910 \quad 10>$. Accessed: Jul. 15, 2019. doi: 10.17660/ActaHortic.2011.910.10.

LIMA, L. L. de A. et al. Otimização e validação de método para determinação de ácidos orgânicos em vinhos por cromatografia líquida de alta eficiência. Química Nova, v. 33, n. 5, p. 11861189, 2010. Available from: <https://www.scielo.br/j/qn/a/ xLDGdK6wsQTKNs8YsrT3ZLh/?lang=pt $>$. Accessed: Jul. 15, 2019. doi: $10.1590 / \mathrm{S} 0100-40422010000500032$.

MARTINS, M. DE L. R. et al. Efeitos da utilização de Smallanthus sonchifolius (yacon) no tratamento de indivíduos com Diabetes Mellitus. CERES: Nutrição \& Saúde (Título não-corrente), v. 6, n. 1, p. 35-43, 2011. Available from: $<$ https://www.e-publicacoes.uerj. br/index.php/ceres/article/view/1969/3650>. Accessed: Jul. 15, 2019.

MENDES, A. H. de L. et al. Sensory acceptance and characterization of yoghurt supplemented with yacon syrup and cashew apple extract as a source of bioactive compounds. Brazilian Journal of Food Technology, v. 22, 2019. Available from: <https://www.scielo. $\mathrm{br} / \mathrm{j} / \mathrm{bjft} / \mathrm{a} / 8 \mathrm{RVgxSkgJ} 7 \mathrm{gvVzGvVZsRGss} / \mathrm{abstract} /$ ?lang=en $>$. Accessed: Jun. 22, 2020. doi: 10.1590/1981-6723.15318.

NARAYANAN, P. et al. Use of just-about-right scales and penalty analysis to determine appropriate concentrations of stevia 
sweeteners for vanilla yogurt. Journal of Dairy Science, v. 97, n. 6, p. 3262-3272, jun. 2014. Available from: <https://www. sciencedirect.com/science/article/pii/S0022030214002185>. Accessed: Jul. 15, 2019. doi: 10.3168/jds.2013-7365.

NIXDORF, S. L.; HERMOSÍN-GUTIÉRREZ, I. Brazilian red wines made from the hybrid grape cultivar Isabel: Phenolic composition and antioxidant capacity. Analytica Chimica Acta, v. 659, n. 1-2, p. 208-215, fev. 2010. Available from: <https://www. sciencedirect.com/science/article/abs/pii/S0003267009015931>. Accessed: Jul. 15, 2019. doi: 10.1016/j.aca.2009.11.058.

OJANSIVU, I. et al. Yacon, a new source of prebiotic oligosaccharides with a history of safe use. Trends in Food Science \& Technology, v. 22, n. 1, p. 40-46, jan. 2011. Available from: $\quad<$ https://www.sciencedirect.com/science/article/abs/pii/ S0924224410002633>. Accessed: Jul. 15, 2019. doi: 10.1016/j. tifs.2010.11.005.

OLIVEIRA, F. L. et al. Mulches for yacon cultivation. Horticultura Brasileira, v. 36, n. 3, p. 389-394, set. 2018. Available from: <https://www.scielo.br/j/hb/a/ xwFDMfQ7xY367r4ZRNrJTPQ/? format=html\&lang=en>. Accessed: Jul. 15, 2019. doi: 10.1590/S0102-053620180317.

ORJUELA, O. C.; VANEGAS, J. A. G. Comportamiento de ácidos cítrico, ascórbico y málico en tomate frente a tres sistemas de conservación. Avances: Investigacion en Ingeniería, v. 9, n. 1, p. 7-13, 2012. Available from: <https://revistas.unilibre.edu.co/ index.php/avances/article/view/2729>. Accessed: Jul. 15, 2019.

PADILHA, V. M. et al. Optimization of synbiotic yogurts with yacon pulp (Smallanthus sonchifolius) and assessment of the viability of lactic acid bacteria. Food Science and Technology, v. 37, n. 2, p. 166-175, 29 maio 2017. Available from: <https://www.scielo. $\mathrm{br} / \mathrm{j} / \mathrm{cta} / \mathrm{a} / 7 \mathrm{rbqf} 77 \mathrm{Sn} 6 \mathrm{~L} 64 \mathrm{NNfwBsXCZf} / \mathrm{abstract} /$ ?lang=en $>$. Accessed: Jul. 15, 2019. doi: 10.1590/1678-457X.14016.

PERIN, L. et al. Avaliação do perfil nutricional, consumo e conhecimento sobre alimentos funcionais de docentes em escolas públicas. Perspectiva, Erechim, v. 39, n.145, p. 73-83, 2015. Available from: $<$ https://www.uricer.edu.br/cursos/arq trabalhos usuario/3278.pdf $>$. Accessed: Apr. 05, 2018.

PETTIFOR, J. M. et al. Vitamin D Deficiency and Nutritional Rickets in Children. In: Vitamin D. Elsevier, 2018. p. 179-201. Available from: <https://www.sciencedirect.com/science/article/ pii/B9780128099636000675>. Accessed: Jul. 15, 2019. doi: 10.1016/B978-0-12-809963-6.00067-5.

RIBÉREAU-GAYON, P. et al. Handbook of Enology, Volume 2: The Chemistry of Wine-Stabilization and Treatments. John Wiley \& Sons, v.2, 2006.

ROCHA, I. F. de O.; BOLINI, H. M. A. Passion fruit juice with different sweeteners: sensory profile by descriptive analysis and acceptance. Food Science \& Nutrition, v. 3, n. 2, p. 129-139, mar. 2015. Available from: <https://onlinelibrary.wiley.com/doi/ full/10.1002/fsn3.195>. Accessed: Jul. 15, 2019. doi: 10.1002/ fsn3.195.

RODRIGEZ-AMAYA, D. B. A guide to carotenoid analysis in food. Washington: International Life Science Institute Press, 2001.
ROLDÁN, C. M.; AZCONA, Á. C. Componentes bioactivos de los alimentos. Nutrition, v. 89, p. 1543S-1548S, 2009. Available from: $<$ https:/www.kelloggsnutrition.com/content/dam/globalnutrition/ es_ES/assets/Manual_Nutricion_Kelloggs_Capitulo_02.2.pdf $>$. Accessed: Jul. 15, $201 \overline{9}$.

SANTHOSHA, S. G. et al. Bioactive components of garlic and their physiological role in health maintenance: A review. Food Bioscience, v. 3, p. 59-74, set. 2013. Available from: $<$ https://www. sciencedirect.com/science/article/abs/pii/S2212429213000473>. Accessed: Jul. 15, 2019. doi: 10.1016/j.fbio.2013.07.001.

SILVA, L. M. R. da et al. Desenvolvimento de bebidas mistas à base de cajá (Spondias mombin 1.) E caju (Anacardium occidentale) enriquecidas com frutooligossacarídeos e inulina. Archivos Latinoamericanos de Nutrición, v. 61, n. 2, p. 209, 2011. Available from: <http://ve.scielo.org/scielo.php?pid=S000406222011000200013\&script=sci_arttext $>$. Accessed: Jul. 15, 2019.

SILVA, M. DE F. G. da et al. Evaluation of nutritional and chemical composition of yacon syrup using 1H NMR and UPLC-ESI-QTOF-MSE. Food Chemistry, v. 245, p. 1239-1247, abr. 2018. Available from: <https://www.sciencedirect.com/science/article/ abs/pii/S030881461731912X >. Accessed: Jul. 15, 2019. doi: 10.1016/j.foodchem.2017.11.092.

SOUSA, S. et al. Antioxidant properties of sterilized yacon (Smallanthus sonchifolius) tuber flour. Food Chemistry, v. 188, p. 504-509, dez. 2015. Available from: <https://www.sciencedirect. com/science/article/abs/pii/S0308814615005932>. Accessed: Jul. 15, 2019. doi: 10.1016/j.foodchem.2015.04.047.

SOUZA, C. C. de et al. Physicochemical characteristics and sensory acceptance of a mixed beverage based on organic apple juice and cardamom tea (Elettaria cardamomum) with allegation of functional properties. Food Science and Technology, n. AHEAD, 1 jun. 2020. Available from: <https://www.scielo.br/j/ cta/a/HdqG66pz5xSSZnQH4SP8MMc/?lang=en>. Accessed: Jul. 15, 2019. doi: 10.1590/fst.35419.

TEIXEIRA, A. P. et al. O efeito da adição de yacon no suco de laranja industrializado sobre a curva glicêmica de estudantes universitários. Alimentos e Nutrição, 2009.

TEIXEIRA, N. S. et al. Development of a fruit smoothie with solid albumen of green coconut. Ciência Rural, v. 49, n. 1, 2019. Available from: <https://www.scielo.br/j/cr/a/ ZppLZDjRGzPW6zbYwz8zCDK/abstract/?lang=en>. Accessed: Jul. 15, 2019. doi: 10.1590/0103-8478cr20180110 .

WANG, J. et al. Antitumor, antioxidant and anti-inflammatory activities of kaempferol and its corresponding glycosides and the enzymatic preparation of kaempferol. PLOS ONE, v. 13, n. 5, p. e0197563, 17 maio 2018. Available from: <https://journals.plos.org/plosone/ article?id=10.1371/journal.pone.0197563>. Accessed: Jul. 15, 2019. doi: 10.1371/journal.pone.0197563.

WOBETO, C. et al. Antinutrients in the cassava (Manihot esculenta Crantz) leaf powder at three ages of the plant. Ciência e Tecnologia de Alimentos, v. 27, n. 1, p. 108-112, mar. 2007. Available from: $<$ https://www.scielo.br/j/cta/a/Sv8vZzx3ptT9LLKsTg4xC6m/ abstract/?lang=en $>$. Accessed: Jul. 15, 2019. doi: 10.1590/S010120612007000100019. 